[Agr. Biol. Chem., Vol. 36, No. 3, p. 451 456, 1972]

\title{
Microbial Transformation of Antibiotics
}

\section{Part I. Isomerization of Showdomycin by Streptomyces Species}

\author{
By Mamoru Ozaki, Tatsumi Kariya, Hiroshi Kato and \\ Toshiaki Kimura
}

\author{
Production Department, Shionogi \& Co., Ltd., Imafuku. \\ Amagasaki, Hyogo
}

Received September 22, 1971

\begin{abstract}
Microbial transformation of the nucleoside analogue antibiotic showdomycin was performed using some Streptomyces species. Both the growing culture and the resting cells of Streptomyces sp. No. 383 arrested the antibacterial activity of showdomycin. The inactivated showdomycin was isolated from the reaction mixture by carbon chromatography and was identified with an isoshowdomycin sample which has been chemically derived from showdomycin. It is conjectured that the conversion of showdomycin to isoshowdomycin results from isomerization by an enzyme of Streptomyces sp. No. 383 .
\end{abstract}

Microbial transformation of antibiotics has already reported by several groups. ${ }^{1-31}$ New antibiotic derivatives yielded by microbial enzymes are sometimes found to be more effective than their parent antibiotics. However, it is more the case that enzymes capable of degrading or inactivating antibiotics are widely distributed in microorganisms. ${ }^{4 \sim 10}$ Argoudelis et al. have shown that an antibacterial agent produced by the transformation of clindamycin by a Streptomyces species was clinically effective. We have attempted the microbial transformation of showdomycin(SHM) into a more effective derivative, using various Streptomyces species isolated from soil samples. SHM (Fig. 1) was first isolated from the culture

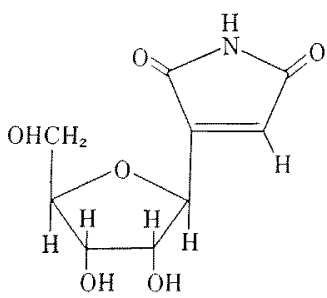

FIG. 1. Showdomycin. broth of Streptomyces showdoensis by Nishimura and co-workers. ${ }^{12 l}$

It is a white crystalline antibiotic of empirical formula $\mathrm{C}_{9} \mathrm{H}_{11} \mathrm{NO}_{6}$, which is active against both gram-positive and gram-negative bacteria and gives cytopathogenic effects on Hela cells.

The antibiotic possesses significant antitumor activity in vivo. SHM has been shown to be more toxic to mice when administered intraperitoneally or subcutaneously than when administered intravenously. In this paper, the microbial transformation of SHM by Streptomyces sp. No. 383 and the identification of the product isolated from the reaction mixture are described.

\section{MATERIALS AND METHODS}

Microorganisms tested. About five hundred strains of Streptomyces species isolated from soil samples were tested for microbial transformation of SHM. The stock medium for these strains was composed of juice extracted from $100 \mathrm{~g}$ of potato with $500 \mathrm{ml}$ of water at $121^{\circ} \mathrm{C}$ for $20 \mathrm{~min}, 5 \mathrm{ml}$ of glycerol, $2 \mathrm{~g}$ of polypeptone, $0.01 \mathrm{~g}$ of $\mathrm{FeSO}_{4} \cdot 7 \mathrm{H}_{2} \mathrm{O}, 0.5 \mathrm{~g}$ of $\mathrm{K}_{2} \mathrm{HPO}_{4}$, $0.5 \mathrm{~g}$ of $\mathrm{NaCl}$ and $20 \mathrm{~g}$ of agar in a total volume of 
$1000 \mathrm{ml}$ water. The $\mathrm{pH}$ was adjusted to 6.0 . Each culture was inoculated into a seed medium containing $10 \mathrm{ml}$ of glucose-nutrient broth $\left(1.00^{\circ}\right.$ glucose, $1.00^{\circ}$ polypeptone, $1.00^{\circ}$ beef extract, $0.50^{\circ} \mathrm{NaCl}$, pH 6.0) in a large test tube and cultured aerobically at $28^{\circ} \mathrm{C}$ for $24 \mathrm{hr}$ on a reciprocal shaker. The seed broth was inoculated into a $500 \mathrm{ml}$ Sakaguchi flask containing $100 \mathrm{ml}$ of a fermentation medium composed of $2.00^{\circ}$ glycerol, $0.20^{\circ}$ glycine, $0.05 \% \mathrm{MgSO}_{4}$. $7 \mathrm{H}_{2} \mathrm{O}, 0.10 \quad \mathrm{~K}_{2} \mathrm{HPO}_{4}, 0.01 \% \quad \mathrm{FeSO}_{4} \cdot 7 \mathrm{H}_{2} \mathrm{O}, 0.02 \%$ $\mathrm{CaCO}_{3}$ and $0.2 \% \mathrm{NaCl}$ (pH 5.5). Incubation was carried out for $24 \mathrm{hr}$ at $28^{\circ} \mathrm{C}$ on a reciprocal shaker.

Transformation of SHM. SHM $(0.5 \%)$ was added to the fermented broth of each strain prepared as described above. The reaction mixture was shaken at $28^{\circ} \mathrm{C}$ for $20 \mathrm{hr}$. Transformation products were checked by paper chromatography. The consumption of SHM used as substrate was determined by microbiological assay.

Assay of SHM and the products. The reaction mixture $(0.02 \mathrm{ml})$ was spotted on a Toyo filter paper No. 50 and developed in a solvent system consisting of $n$-butanol, ethylacetate, pyridine and water( $5: 2: 1: 1)$. Each substance on the paper was detected under an ultraviolet lamp equipped with a $2537 \AA$ filter. The concentration of residual SHM was assayed by the pulp disk method using Bacillus subtilis PCI-219 as the test organism. The medium for this bioassay was a synthetic one consisting of $1.0 \%$ glucose, $0.1 \%$ $\left(\mathrm{NH}_{4}\right)_{2} \mathrm{HPO}_{4}, \quad 0.1 \% \mathrm{KH}_{2} \mathrm{PO}_{4}, \quad 0.5 \% \mathrm{NaCl}, 0.04 \%$ $\mathrm{MgSO}_{4} \cdot 7 \mathrm{H}_{2} \mathrm{O}$ and 1.00 agar. The $\mathrm{pH}$ was adjusted to 6.0 before sterilization. Also, bioautography was carried out by the following procedure. The paper chromatogram of the reaction mixture was placed on the surface of an agar plate(synthetic medium) seeded with the test organism, and stripped off after $20 \mathrm{~min}$. The agar plate was incubated at $28^{\circ} \mathrm{C}$ overnight and the inhibitory zones which appeared were checked against the spots on the paper chromatogram.

\section{RESULTS}

\section{Screening of microorganisms}

To find microorganisms which can transform SHM into a derivative, about five hundred strains of Streptomyces species isolated from various soil samples were tested by the following procedure. SHM $(0.5 \%)$ was added in the fermented broth of each growing culture and incubated for $20 \mathrm{hr}$ at $28^{\circ} \mathrm{C}$. Some of the results are shown in Table I. Among the

Table I. Consumption of SHowdomycin by Streptomyces SPECIES

Reaction was conducted with a SHM concentration of $5 \mathrm{mg} / \mathrm{ml}$ in each growing culture at $28^{\circ} \mathrm{C}$ for $20 \mathrm{hr}$.

\begin{tabular}{rrccc} 
Strains & $\begin{array}{c}\text { Initial } \\
\mathrm{pH}\end{array}$ & $\begin{array}{c}\text { Residual SHM } \\
(\mathrm{mg} / \mathrm{ml})\end{array}$ & $\begin{array}{c}\text { Final } \\
\mathrm{pH}\end{array}$ \\
\hline No. 57 & 5.3 & 4.9 & 5.0 \\
160 & 5.2 & 0.7 & 4.8 \\
177 & 4.9 & 1.0 & 5.1 \\
279 & 5.4 & 4.8 & 5.1 \\
383 & 4.8 & 0.0 & 7.0 \\
395 & 5.3 & 2.0 & 4.8 \\
423 & 6.2 & 0.9 & 5.7 \\
427 & 6.6 & 0.3 & 6.3 \\
447 & 5.6 & 1.2 & 6.8 \\
$48 \mathrm{I}$ & 4.8 & 4.6 & 4.1 \\
\hline
\end{tabular}

microorganisms tested, only Streptomyces sp. No. 383 gave the positive result. This strain accumulated a new compound in high yield, which was easily distinguished from SHM by the paper chromatographic examination (Fig. 2). The compound lacked antibacterial activity against Bacillus subtilis in the bioauto-

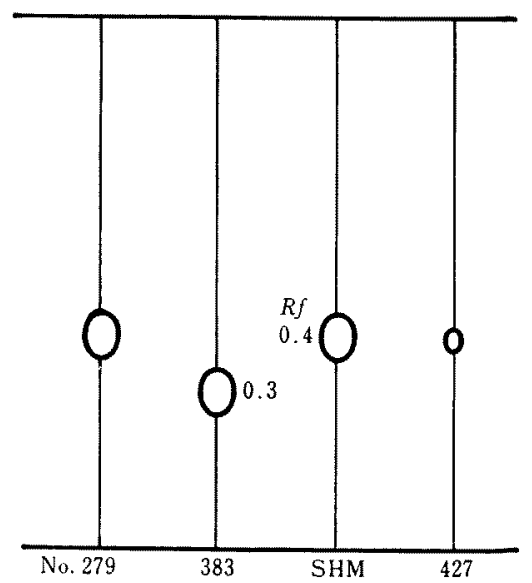

FIG. 2. Paper Chromatogram of Representative Reaction Mixtures. 
graphy. Streptomyces sp. No. 427 also degraded SHM, but no detectable substance was accumulated.

\section{Inactivation of SHM by resting cells of Strepto-} myces sp. No. 383

Streptomyces sp. No. 383 was cultured as described above. Cells grown in the medium during $24 \mathrm{hr}$ of shaking were collected by centrifugation at $3000 \times g$ for $10 \mathrm{~min}$ and washed twice with $1 / 15 \mathrm{M}$ phosphate buffer(pH 5.5). The cells were homogeneously resuspended in the same buffer at a concentration of $15 \mathrm{mg}$ dry weight per $\mathrm{ml}$. The suspension of washed cells(resting cells) readily inactivated SHM and the product accumulated was identical to that obtained by using the growing culture. These results strongly suggest that SHM was inactivated by an intracellular enzymatic system of this strain(Table II). The effect of

TABLE II. INACTIVATION OF SHM BY THE Ciells and Supernatant of Streptomyces sp. No. 383

\begin{tabular}{lccc} 
& $\begin{array}{c}\text { Initial } \\
\mathrm{pH}\end{array}$ & $\begin{array}{c}\text { Residual SHM } \\
(\mathrm{mg} / \mathrm{ml})\end{array}$ & $\begin{array}{c}\text { Final } \\
\mathrm{pH}\end{array}$ \\
\hline Growing culture & 6.5 & 0.9 & 5.7 \\
Supernatant & 6.5 & 4.0 & 4.5 \\
Cells ${ }^{a}$ & 5.5 & 0.0 & 6.8
\end{tabular}

a) The cells were suspended in 1/15 M phosphate buffer $(\mathrm{pH} 5.5,15 \mathrm{mg} / \mathrm{ml}$ as dry cells). Reaction was conducted for $3 \mathrm{hr}$ at $28^{\circ} \mathrm{C}$ with $\mathrm{SHM}(5 \mathrm{mg} / \mathrm{ml})$.

SHM concentration on the rate of its conversion is shown in Fig. 3.

The yield of the product was almost 100,8 at any level of $\operatorname{SHM}\left(0.5 \sim 3.090^{\prime}\right)$ tested.

\section{Isolation and identification of inactivated $S H M$}

Transformation of SHM with the resting cells of Streptomyces sp. No. 383 was carried out as described above. After removal of cells by centrifugation, the supernatant fluid was passed through a column of carbon. The column was washed with water and eluted with

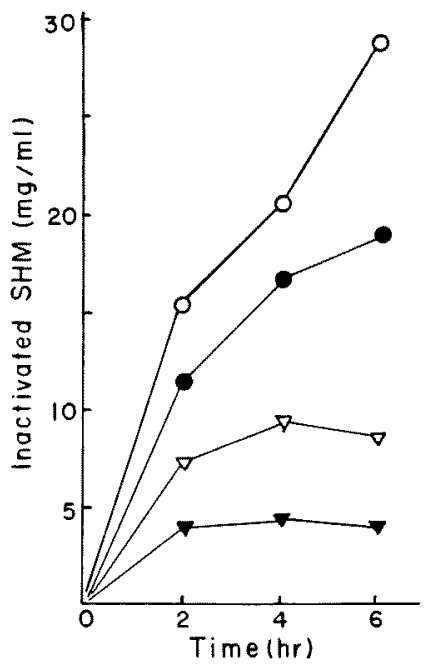

FIG. 3. Effect of SHM Concentration on the Transformation of SHM by the Resting Cells of Streptomyces sp. No. 383.

O-O 30 SHM was added.

$-2 \%$ SHM was added.

$\nabla-\nabla 10.5$ SHM was added.

$\nabla-\nabla 0.50^{\circ}$ SHM was added.

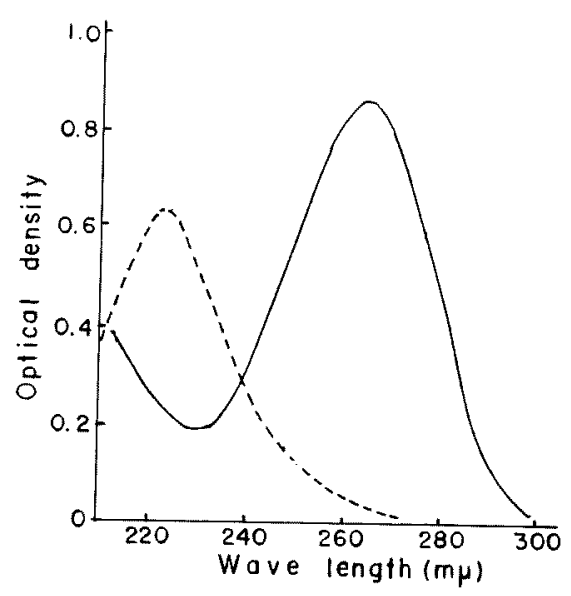

FIG. 4. Ultraviolet Absorption Spectra of SHM and Inactivated SHM.

$$
\text { ... SHM, - Inactivated SHM. }
$$

$80 \%$ acetone. The eluate was concentrated in vacuo to facilitate crystallization and the 


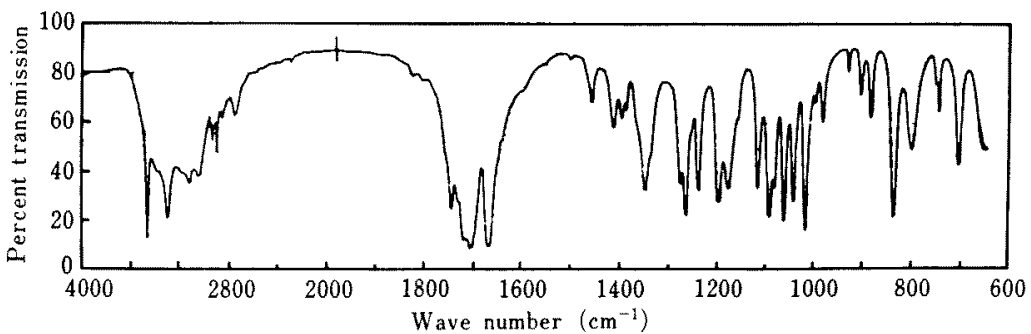

FIG. 5. Infrared Spectrum of Inactivated SHM.

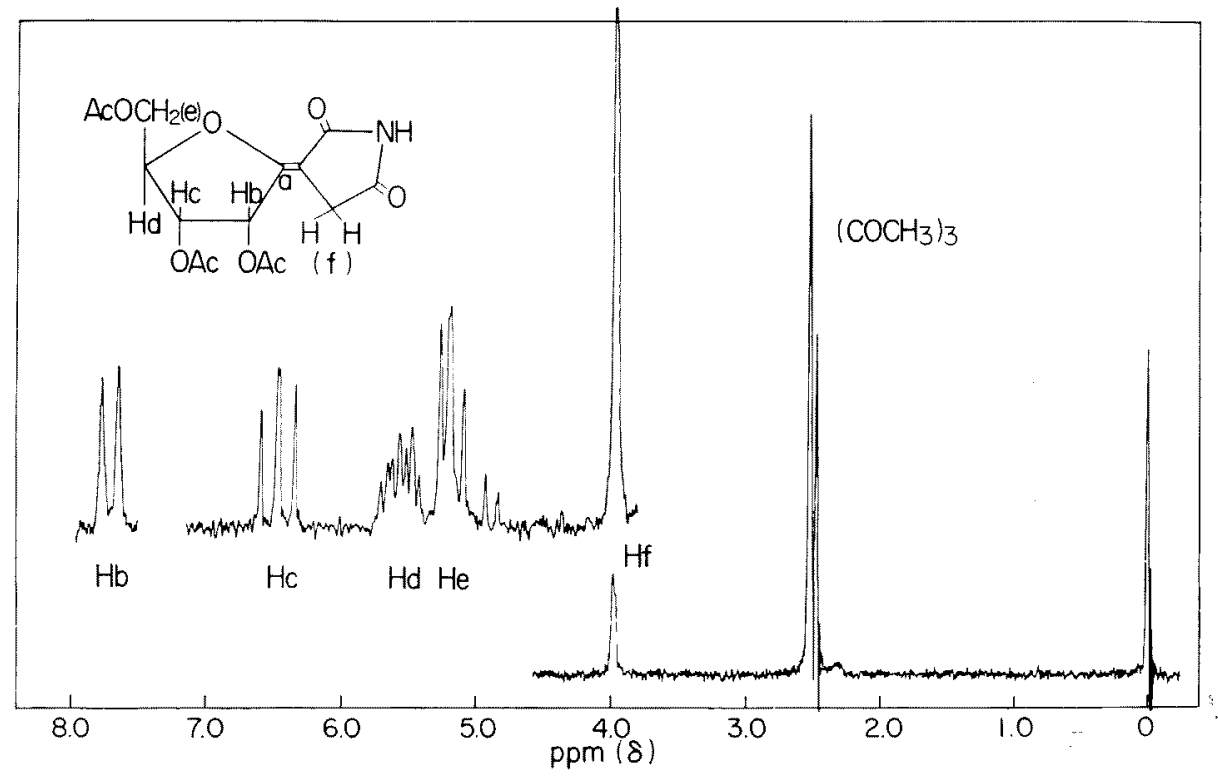

FIG. 6. NMR Spectrum of Triacetate of Inactivated $\mathrm{SHM}$ in $\mathrm{CDCl}_{3}$ at $60 \mathrm{MHz}$.

crude material obtained was repeatedly recrystallized from a small amount of hot water. The crystals obtained by this procedure were white needles, $\mathrm{mp} 215 \sim 216^{\circ} \mathrm{C},[\alpha]_{\mathrm{D}}^{22.5}-34.0$ $\left(c=1, \mathrm{H}_{2} \mathrm{O}\right)$. Anal. Found: C, 47.18; H, 4.81; $\mathrm{N}, 6.12$; mol. wt. 229(mass spectrometry). Calcd. for $\mathrm{C}_{9} \mathrm{H}_{11} \mathrm{NO}_{6}: \mathrm{C}, 47.16 ; \mathrm{H}, 4.81 ; \mathrm{N}$, $6.11 \%$. From these data, it was considered that the product is an isomer of SHM. The UV absorption spectrum of the product is given in Fig. 4. Its spectrum is characterized by a maximum at $264 \mathrm{~m} \mu(\log \varepsilon 4.3)$, different from that of SHM(maximum at $222 \mathrm{~m} \mu$ ). In order to determine the structure of the inactivated SHM, IR and NMR spectra were taken. The IR spectrum shows the characteristic bands: $3490,3325,3080(\mathrm{OH}, \mathrm{NH}), 1753,1727,1713$, $1677(\mathrm{C}=\mathrm{C}, \mathrm{C}=\mathrm{O}) \mathrm{cm}^{-1}$ (Fig. 5). Inactivated SHM was easily acetylated with acetic anhydride and phosphoric acid. An analytical sample of the acetate(triacetate) gives the following analysis. Found: C, 51.89; H, 4.96; N, 3.83; mol. wt. 355(mass spectrometry). Calcd. for $\mathrm{C}_{15} \mathrm{H}_{17} \mathrm{NO}_{9}: \mathrm{C}, 52.17 ; \mathrm{H}, 4.78 ; \mathrm{N}, 3.94 \%$. 
The acetonide of inactivated SHM was prepared by reaction with acetone and conc. $\mathrm{H}_{2} \mathrm{SO}_{4}$. Anal. Found: $\mathrm{C}, 53.28 ; \mathrm{H}, 5.46 ; \mathrm{N}$, 5.12. Calcd. for $\mathrm{C}_{12} \mathrm{H}_{15} \mathrm{NO}_{6}: \mathrm{C}, 53.53 ; \mathrm{H}, 5.63$; $\mathrm{N}, 5.20 \%$. The formation of an acetonide shows that two of the three hydroxyl groups should, if they are vicinal, have a cis configuration. These results suggest that the structure of inactivated SHM contains of a furanose ring. The NMR spectrum of the triacetate is shown in Fig. 6. From analysis of the spectrum in deutrochloroform seven protons ( $\mathrm{Hb}, \mathrm{Hc}, \mathrm{Hd}, 2 \mathrm{He}$ and an olefinic proton $\mathrm{Hf}$ ) can be assigned, but the $\mathrm{Ha}$ proton signal recognized in the NMR spectrum of triacetyl SHM was absent in the spectrum of the triacetate of inactivated SHM. Moreover, the NMR spectrum of inactivated SHM was the same as that of an isoshowdomycin sample prepared from SHM chemically by Nakagawa and co-workers. ${ }^{13)}$ On the basis of this physicochemical evidence; one possible structure is proposed for inactivated $\mathrm{SHM}$ (Fig. 7). The

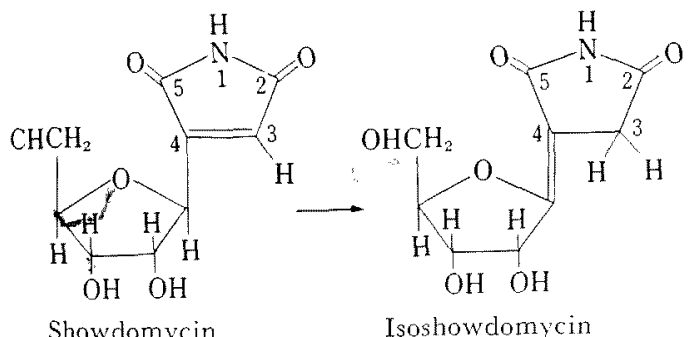

FIG. 7. The Conversion of Showdomycin to Isoshowdomycin.

findings suggest that the transformation of SHM to isoshowdomycin is the result of isomerization by an enzyme of Streptomyces sp. No. 383.

\section{DISCUSSION}

The purpose of our research is to establish a biochemical method for the transformation of showdomycin into a more effective, ufiliz- able material. We found that SHM was readily attacked by Streptomyces sp. No. 383, but the product unfortunately lacked antibiotic activity against both gram-positive and gramnegative bacteria. Inactivated SHM was isolated by column chromatography and identified as isoshowdomycin. The results suggest that the presence of a double bond $\left(\mathrm{C}_{3}=\mathrm{C}_{4}\right)$ in the maleimide moiety of SHM is necessary for antibacterial activity(Fig. 7). Therefore, microbial transformation and chemical modification of SHM must be carefully carried out with protection of the double bond. Shirato et al. . $^{\prime}$ have reported the enzymatic phosphorylation of a nucleoside analogue antibiotic, tubercidine, with Serratia marcescens and $p$-nitrophenyl phosphate, and they found that the toxicity of the phosphorylated compound was considerably less than that of tubercidine. Although the antibiotic activity against microorganisms was simultaneously reduced, this tubercidine derivative still seemed to be sufficiently effective for evaluation as an chemotherapeutic agent. We wish to continue our research for the production of improved antibiotic derivatives by effective microorganisms.

Acknowledgment. The authors wish to thank Dr. E. Kondo and Dr. Y. Nakagawa of Shionogi Research Laboratory for their helpful advice and discussion.

\section{REFERENCES}

1) D. Periman, A. B. Mauger and H. Weissbach, Antimicro. Agents and Chemoth., 1966, 581.

2) A. D. Argoudelis and D. J. Mason, J. Antibiotics, 22, $289(1969)$.

3) A. Capek, A. Simek, E. Svátek and M. Buděs̈insky, Fol. Microbiol., 14, 557 (1919).

4) S. Shirato, K. Yoshida and Y. Miyazaki, J. Ferment. Technol., 46, 233 (1968).

5) A. D. Argoudelis and J. H. Coats, J. Antibiotics, 22, 341 (1969).

6) idem, ibid., 24, 206 (1971).

7) M. Nishida, Y. Yokota and T. Matsubara, ibid,, 22, 381 (1969).

8) C. T. Hou, D. Perlman and M. R. Schallok, ibid, 23, 35 (1970). 
9) C. T. Hou and D. Perlman, J. Biol. Chem., 245, 1289 (1970).

10) A. Capek, A. Simek, J. Turnová and J. Tuma, Fol. Microbiol, 14, 94 (1969).

11) A. D. Argoudelis, J. H. Coats, D. J. Mason and O. K. Sebek, J. Antibiotics, 22, 309 (1969).
12) H. Nishimura, M. Mayama, Y. Komatsu, H. Kato, N. Shimaoka and Y. Tanaka, J. Antibiotics, Ser. A, 17, 148 (1964).

13) Y. Nakagawa, K. Harada and H. Kano, unpublished data. 